\title{
A Research-Based Teacher Education in Finland-A Dilemma for the Students
}

\author{
Gunilla Eklund \\ Åbo Akademi University, Vasa, Finland
}

\begin{abstract}
The aim of the study is to investigate student teachers' views of the research-based teacher education in Finland. Data were collected at Åbo Akademi University, and at the end of the education, 69 student teachers wrote essays about their views of having research studies and writing scientific theses. The essays were analyzed in an inductive way and meaning categorization was used as the method of analysis. As a result of the analysis, three main aspects were identified: students' positive and negative views of as well as their alternatives to the research studies and the scientific thesis. According to the results, the research-based teacher education means a dilemma for the students. They understand it and they see the point with it, but at the same time, they feel that it does not give them enough practical tools before entering the reality as a real teacher.
\end{abstract}

Keywords: teacher education, research-based, scientific thesis, research oriented studies

\section{Introduction}

During the last years, the educational system in Finland has got much publicity (Sahlberg, 2011). According to the OECD (Organisation for Economic Co-operation Development) Programme for International Student Assessment, Finland performed once again very well according to the PISA (Programme for International Student Assessment) 2009 investigation. Finnish schoolchildren achieved very high results in both reading, mathematics, and natural science (Harju-Luukkainen \& Nissinen, 2010; Simola, Rinne, Varjo, \& Kauko, 2013). One main reason for Finland's success seems to be the quality of the teacher education. As a consequence, the interest for the Finnish teacher education has largely increased during the last years and for example educational reforms in other Nordic countries have been inspired by the Finnish teacher education. However, what is the secret of the Finnish teacher education?

Over the past two decades, primary school teacher-education in Finland has been reconstructed in direction to a research-orientation. In the past, teacher education for primary school teachers has its origin in a seminaristic tradition and the teachers were educated in seminars. In the 1970s, teacher education for primary school changed and was incorporated into the university system. From the 1980s, primary school teacher-education became fully integrated and linked to a master's degree. As a consequence of the reform, teacher education is now arranged at faculties of education in eight of Finland's universities. A teacher training school is connected to every teacher education and most practical teacher training is carried out at these training schools. The primary school teacher education in Finland is thus university based and leads to a master's degree.

Gunilla Eklund, Ed.D., associate professor, Faculty of Education, Åbo Akademi University. 
In 2005, the teacher education in Finland was changed in accordance with the Bologna reform (Jakku-Sihvonen \& Niemi, 2006). As a result of the reform, research and science were even more emphasized and the relation between theory and practice was focused on. The teacher education now consists of a two-cycle degree system, i.e., undergraduate studies leading to a bachelor's degree and graduate studies resulting in a master's degree. According to the European Credit Transfer System, the education is 300 points and planned to be carried out in five years. Student teachers have research oriented studies at both levels. At the Bachelor of Education Level they write a candidate thesis (6 ECTS) and at the Master of Education Level they write a master thesis (35 ECTS). The students have also method courses at both levels, aiming at teaching students how to carry out a research process and write a scientific thesis (Eklund, 2010; Hansén, Sjöberg, \& Eklund-Myrskog, 2005; Sjöberg \& Hansen, 2011). The faculties of education and departments of teacher education provide full programmes up to doctoral level and it is possible for the student teachers to apply for postgraduate studies directly after completed master's degree. In 2006-2007, a ministerial committee was appointed in order to visualize Finnish teacher education up to the year 2020 (Lärarutbildning 2020, 2007). According to the committee no major changes should be done with regard to the basic structure of Finnish teacher education, i.e., its research-based approach. This statement thus strengthens the profile of the present teacher education.

The aim of the research-orientation is that the students get a preparedness to systematically and in a reflective way investigate issues and as a consequence develop their own practice as professional teachers. The aim is thus related to the view of a professional and reflective teacher. The scientific theses are also meant to have significant relevance to the teaching profession while the thesis works mean that the students become familiar with scientific tools such as methods for gathering data, systematic analytic thinking, and interpretation and evaluation. All these components are of significant use in a reflective teacher practice.

However, although the research-based teacher education has got much publicity and credit, the research-orientation of the Finnish teacher education has also been discussed and criticized (Hansen, Forsman, Aspfors, \& Bendtsen, 2012; Westbury, Hansén, Kansanen, \& Björkvist, 2005). For example, Hansen et al. (2012) point out four dilemmas in the Finnish teacher education, one of them is the relation between the research-based and practice-oriented approaches. Although the aim of the research-orientation is related to the view of a professional and reflective teacher, the relation between theory and practice cannot be taken for granted (for example, Komulainen, 2010).

\section{Aim of the Study}

In several studies carried out at the Department of Teacher Education at Åbo Akademi University, students' views of the research-based teacher education have been investigated (Eklund, 2010, 2012; Eklund-Myrskog, 2006, 2007). The results show that at the beginning of the research process, the students have a quite confuse and divergent view of the research-based teacher education. However, the interesting and relevant question is in what way students' view of the teacher education may change during the education? The overall aim of this study is thus to investigate students' views of having research courses and writing a scientific thesis at the very end of the teacher education.

\section{The Empirical Study}

The aim of investigating student teachers' views of having research courses and writing a scientific thesis 
implies a qualitative approach. The study is thus qualitative in character and the phenomenographic approach is taken as the point of departure. In the phenomenographic approach, the central term is "conception", which means the fundamental way a person understands a phenomenon or an object in the surrounding world. A conception is not visible but can be seen as a qualitative relationship between an individual and some phenomenon. According to the phenomenographic approach, individuals perceive and understand reality in different ways, and the aim is to describe these qualitatively different ways people conceptualize and understand phenomena in or aspects of the surrounding world (see for example, Bowden \& Walsh, 2000; Marton \& Tsui, 2004).

Data for the empirical study were collected at the Department of Teacher Education at Åbo Akademi University. A total number of 75 student teachers participated in an advanced research course. Qualitative research methods and analysis (4 ECTS). At the end of the course, the students were asked to write essays about their views of having research courses and writing a thesis within teacher education. The choice of participants in most qualitative studies is characterized by the ambition to gain as great a variation as possible in relevant aspects of the group under investigation. The reason for choosing a heterogeneous group for investigation is that the researcher is then probably able to optimize the variation of the phenomenon that is to be described. In this study, the group was very heterogeneous concerning sex, age and previous research experiences within teacher education. A total amount of 69 essays (about 1-3 A4 pages long) were collected from the students. The essays were analyzed in an inductive way and meaning categorization was used as the method of analysis.

The analysis of the essays was carried out in several stages. In the beginning, the researcher perused all essays and marked the parts were students expressed their views of having research courses and writing a scientific thesis. In accordance with the aim, the students' essays were then analyzed in relation to three phenomena and one phenomenon at a time. The researcher perused the selected part in every essay, underlined the most essential sentences and wrote down keywords characterizing the student's view of the phenomenon in focus. The sentences underlined and the keywords in the essays were then compared with each other in order to find qualitative similarities and differences between the students. Content specific similarities and differences between students' utterances concerning a certain phenomenon or research question were noted and then described and categorized in terms of qualitatively different categories of description. Qualitatively different means different ways of conceiving the phenomenon, not in terms of the amount of detail provided but rather in relation to their structural meaning. Each category thus represents a unique way of understanding the aspect in focus. These categories together define a category system. Since the aim of the study was to investigate three different phenomena, the qualitative analysis finally resulted in three different category systems based on these phenomena. The categories within each category system are to be considered as equal in relation to each other. In the categorization they are arranged according to the principle of the number of students. The students could express different views of the phenomenon in focus and this means that the students were classified in accordance with their different views. Consequently, each student was classified in one or more categories of description for each phenomenon (Dahlgren \& Fallsberg, 1991).

\section{Results}

As a result of the inductive analysis, three main aspects concerning students' views of the research studies and the thesis were identified. The three aspects are: 
(1) Students' positive views of the research studies and the scientific thesis;

(2) Students' negative views of the research studies and the scientific thesis;

(3) Students' alternatives to the research studies and the scientific thesis.

\section{Students' Positive Views of the Research Studies and the Scientific Thesis}

Generally, all students experienced the research studies and the thesis in a positive way and as many as 185 positive views could be identified in the students' essays. These views were categorized into nine categories of description (see Table 1).

Table 1

Students' Positive Views of the Research Studies and the Scientific Thesis

\begin{tabular}{|l|l|l|}
\hline 1 & Deep knowledge in a subject & 34 \\
\hline 2 & Master education and higher status & 30 \\
\hline 3 & Professionalism & 29 \\
\hline 4 & Understanding and ability to carry out studies & 22 \\
\hline 5 & Maturity and personal development & 17 \\
\hline 6 & Critical thinking & 16 \\
\hline 7 & Good language & 15 \\
\hline 8 & Interest for further research & 14 \\
\hline 9 & Contribution to something new & 8 \\
\hline
\end{tabular}

Most students $(n=34)$ experienced that the research studies and the scientific thesis give them deep knowledge into a certain subject. The fact that the thesis offers a unique opportunity for the students to independently choose and deepen a pedagogical topic was thus pointed out by the students. The students explained that the thesis means a possibility for them to specialize in a topic of personal interest and become professionals in that subject. Consequently, the students saw the chance to deepen their knowledge about a specific topic and become professionals in that subject in both a personal and a professional way. "I have the opportunity to deepen my knowledge into a subject I am interesting in and I need to get more knowledge of", in the students' essays, it was obvious that they were not only interested in getting insight into specific pedagogical subjects and issues. Some students also related the achieved top competence to themselves in a more general way. Consequently, this means that the students saw the relevance of getting deep knowledge into a subject in relation to a personal and wider perspective, "I think that the research studies and the thesis give us a better understanding of society in general".

Many students $(n=30)$ pointed out the importance of having research studies and writing a scientific thesis in order to get a university examination and a master's degree. The master's degree gives the students formal teacher competence and in this sense they really need it for the future teacher profession, "The teacher education is a master education, which means that research is a part of the education". Some students also emphasized that a master education gives them higher status. The status is important, not only for the students themselves, but also for the teacher profession, "A master education is needed... the teacher profession gets higher status and status is really needed in order to keep the popularity of the profession". In Finland, the teachers have quite high status, which was by some students explained by the research-based education.

A number of 29 students related the research studies and scientific thesis to their future role as professional teachers. The students pointed out that theory and practice are two sides of the same whole, and in order to become professional and good teachers, they need insight into both, "The teacher needs new research 
in order to develop teaching otherwise the school will still be at the same level as 100 years ago. Every teacher wants to be a good teacher and that's why it should be stupid to ignore the world of the research". The students thus saw the research studies and the thesis as a tool for higher competence and professionalism. The students further emphasized that research gives them a theoretical basis in form of new insights and knowledge which help them better understand and handle issues in the everyday life as a teacher, "Every thesis concerns situations, thoughts, and experiences existing in the real life. The relation to the pedagogical field means that the result shows the reality we meet when we begin to work". More specifically, the students experienced that research gives them tools for planning, structuring, acting, analyzing, and evaluating in the practice. For example one student wrote that if the teacher has problems with bullying, he or she should find the solution to the problem in the research done in the field. Consequently, the research studies and the thesis were thus seen by the students as an essential part of the teacher profession.

Altogether 22 students conceived that the research studies and the scientific thesis give them a better understanding of and ability to carry out research by themselves. Some students referred to a better ability to read and understand scientific texts, investigations, and research in general. As a consequence, the doorstep to read theses and studies becomes lower. By writing a thesis the students also get an insight into the disposition of empirical studies and get a better understanding of the research process in itself, "You better understand what scientific research is about, what it really is and how it is done". Some students also related the importance of understanding research to the teacher profession in a more specific way. A teacher continuously needs to read and understand scientific texts and investigations in order to be updated in the pedagogical field. After having written the thesis, it is easier for the students to choose and read relevant research for the profession, "I will be working in physical education and that's way I think I will benefit from being able to read diagrams, investigations and such, often used in the field". Finally, some students pointed out that a teacher also has a role as a researcher and need to be able to do own research. The research studies and the thesis thus give the students tools and experiences that is needed when they as teachers investigate their own activity or when the school evaluates its own school culture.

Seventeen students pointed out the process in writing a scientific thesis. The students experienced the process in a very personal way and saw the result of it in terms of maturity and personal development. Some of the students related the maturity and the development to themselves in a general way. The conceived that the process increases their self-discipline, their ability to take responsibility, and their capability to think in an intellectual way. Most students also related the process explicitly to the teacher profession in preparing and making them stronger for the future job. The personal development as a result of the scientific writing was thus seen by the students as very relevant for the teacher profession, "The process means that the students become more mature. The maturity occurs on many different levels. You become more independent, you improve your ability to reflect and think in a critical way on different levels and to cognitively work with several things at the same time. These are invaluable qualifications for a teacher". Consequently, the students experienced that the result of the research studies and the writing of a thesis in form of maturity and personal development make them to better teachers. In this way, the students expressed a very professional view of the research-based teacher education and understood the overall aim of it.

Sixteen students pointed out that by having the research studies and writing the scientific thesis they develop their critical thinking. They then better understand different studies and investigations, and they can evaluate new information in a more critical way, "After having written the thesis, you have a better ability to 
understand research and different investigations... The ability to evaluate new information in a critical way is important in the everlasting flow of information". Some students also related the critical thinking to the future teacher profession and pointed out the relevance of having such an approach also in the everyday work. As a teacher, it is also important to support the pupils' critical thinking. The pupils get more a role as researchers and they should in a more active way look for knowledge and information. In this process, the teacher has an essential role, helping them being critical in a positive way, "The pupils will do research in different subjects, and as a teacher I am responsible for giving the pupils a critical thinking concerning references, literature, and the use of internet".

The development of the written language was lifted up by 15 students and the fact that the research studies and the scientific thesis improve their ability to write. In the students' essays, it was obvious that they related the ability to write mainly to the teacher profession and the teaching process, "You develop very much during the writing process in this sense. The language is one of the teacher's most important tools, and that's way it is so important that his or her use of language is correct". However, some of the students also pointed out that a professional teacher needs to have a good language in general, not only for the teaching in the classroom, "After having written a thesis, you hopefully have such good a language that you can easily write and discuss most things in the society. With the help of this ability we may have an impact on the society, except for the one we already have as teachers".

Fourteen students pointed out the research studies and the scientific thesis as a good basis for further research. They related writing a thesis to a future research carrier and they expressed an interest and ambition to keep on researching after having written the thesis. The students conceived the research studies often as challenging and difficult. However, after having written the thesis, they felt that the step forward towards further research was smaller, "By writing a thesis, the primary school teachers become more involved in the world of research and this can be a gateway to doing research full-time". Some students also related the importance of doing research, not only to themselves, but to the Swedish-speaking school in Finland in general, "It's important to do research within the Swedish-speaking school in order to keep our school-system on top-level also in the future".

Finally, according to eight students, a positive aspect of the research studies and the scientific thesis was the contribution of something new. The students pointed out that they by writing the thesis contribute with new information, knowledge, results, and research in general, "You contribute with new information and new results, as a primary school teacher you want to do that". The contribution was seen by the students primarily for the pedagogical field, but also for the society in general, "The thesis means a distribution the world can take advantage of. Your research may show a certain problem, you may find a solution to an already existing problem, and improve our school environment or facilitate our work as teachers".

\section{Students' Negative Views of the Research Studies and the Scientific Thesis}

Generally, all students experienced the scientific writing in a positive way and 36 of these students only expressed positive views of the research studies and the thesis. However, a number of 33 students also expressed negative views of the research studies and the thesis. These 33 students expressed altogether 48 views, which could be categorized in six qualitatively different categories of description (see Table 2).

Almost all students $(n=28)$ who expressed negative views of the research studies and the scientific thesis experienced that the relation between the research studies and the teacher profession was too weak. The 
students felt that they in their future job as a primary school teacher do not need research studies or a thesis. Consequently, they did not really understand in what way the research-based teacher education would prepare them for the future teacher profession. The students had thus difficulties in relating the role as a researcher to the role as a teacher in the field, "I feel insecure in what way I can benefit from my experiences of having written a thesis when I am working as a teacher. I think that my role as a researcher is quite far away from my role as a professional teacher". Some students also explained more specifically in what way they experienced the research studies and the thesis as irrelevant for the teacher profession. The students pointed out that the teacher work is a practical profession and they do not need the research studies and that kind of knowledge in the everyday life, when teaching and working in the classroom. In order to educate more professional teachers who are well-prepared for the profession, the practical and theoretical studies should thus be in a better balance within the education than at present. The students experienced that the reality they meet is another one than the one they are studying for and that the competence they really need they do not always achieve.

Table 2

Students' Negative Views of the Research Studies and the Scientific Thesis

\begin{tabular}{|l|l|l|}
\hline 1 & Weak relation to the teacher profession & 28 \\
\hline 2 & Too large part of the education & 13 \\
\hline 3 & Pressure and performance anxiety & 3 \\
\hline 5 & Too theoretical education for a practical profession & 2 \\
\hline 6 & No support for critical thinking & 1 \\
\hline
\end{tabular}

Thirteen students experienced that it is too much focus on the research studies and the scientific thesis in the education. Studying research methodology and writing a thesis is a very demanding process, both resourceand time-consuming and this fact was seen by the students in a negative way. Students experienced the focus on research, especially at the end of the education, as very irrelevant in relation to the upcoming teacher profession. Instead for research the students preferred to have practice or other, according to them, more relevant courses, "The question is if the time we spend on learning research methodology would be more useful spending on other courses aiming at developing us as better teachers instead...". The weak relation between the students' own research and the teacher profession was thus experienced as most problematic for the students. The writing of a thesis felt meaningless in relation to the reality newly qualified teachers meet. The students felt that the focus on the research and the evaluation of their thesis was wrong in relation to what is then really required as professional teachers in the field, "I don't study pedagogy in order to become a researcher, I study pedagogy in order to become a teacher. It's too much focus on scientific writing instead of practical exercises and tasks I will be working with during the rest of my life".

Only three students felt anxious and were worried about writing the scientific thesis. One student described in general terms that she felt a tremendous pressure to achieve, while another student pointed out that while she write so badly, the motivation decreases at the same time as the pressure increases. Based on bad experiences from the candidate thesis one students also experienced the whole process as very unpleasant, "I think it's a terrible pressure writing a thesis. I get stomach aches only by thinking of it.... It only feels that it is a huge pressure to make something big and good and magnificent...”.

Two students experienced that the scientific thesis is a too theoretical end of an education aiming at a 
practical profession. As an alternative to the thesis they suggested a skills test. That kind of practical test would to a larger extent show the real competence the student teachers have achieved during the education, "When we write a thesis as a final work it looks like as we are becoming researchers instead of primary school teachers. A well-done thesis shows how good researchers we are, not how good teachers we are".

According to one student, the problem with the scientific writing is that you do not have to think for yourself. The student compared the writing with the discipline of the Finnish military. The student should not dispute, only write on the basis of certain criteria. To write a method chapter... you only have to find a similar thesis and form it into your own words. It is about discipline, it feels unnecessary, but you have to do it, in the same way as in the military, "Move the stone five meters to the right! You should not dispute, only write the method chapter-move the stone".

Finally, one student thought that the problem is the fact that the result of the research does not reach the field. Consequently, there is no larger social use, while it is quite few people who read the theses written by the students, "The problem is that the results of the research may not reach the schools. It is also at this point one can question the system. If we ignore the use of writing a scientific work for the process in itself, is there any larger social use? Everyone who writes a thesis hopes it will have an impact in the field. But unfortunately, I think it is quite few who finally read one's thesis".

\section{Students' Alternatives to the Research Studies and the Scientific Thesis}

The majority of the students $(n=45)$ did not give any concrete alternatives to the research studies and the thesis. However, this does not mean that the students were satisfied with the studies. Many of them had also a negative attitude to the research studies and the thesis, although they did not give any alternatives. In the essays, 24 students gave a total of 45 concrete alternatives for in what way the courses in research studies and the thesis could be developed. The students' alternatives could be categorized into two main groups, Practice and practice-related work, and different courses, and these were finally categorized in six qualitatively different categories of description (see Table 3).

Table 3

Students' Alternatives to the Research Studies and the Scientific Thesis

\begin{tabular}{|l|l|l|}
\hline 1 & Practice in the field & 15 \\
\hline 2 & Practice-related work & 4 \\
\hline 3 & Practical courses & 6 \\
\hline 4 & Courses in special education & 5 \\
\hline 5 & Courses in pedagogy and general subjects & 3 \\
\hline 6 & Courses in pre-school education & 2 \\
\hline
\end{tabular}

Fifteen students suggested that the research studies and the scientific thesis would be replaced with more practice in the field. The practice would for example be a longer practice period and carried out in normal schools. The students generally experienced that the research studies and the thesis had too much focus in the education at the expense of practice. Instead they wanted to spend more time in a school to get more experience and to learn to become a real teacher. Students thought that they do not develop in the same way when they write than when they are out in the field and get insight into a teacher's everyday life, including everything that happens outside the classroom. The students also emphasized the importance of getting teaching experience in order to manage later in the profession. In relation to the practice, the students thus thought that the thesis was 
not so useful. During the practice, however, the students experienced they grow as teachers and develop their teacher characteristics. The students thus thought that the teacher education was too theoretical in its construction and does not give enough preparation for the professional life. As a consequence, the students believe that many newly qualified teachers experience the first time in the teacher profession as problematic. In order to have better opportunities to manage as newly qualified teachers, the students would like to get more experience of concrete teaching and the teacher's everyday life, "Many students think that the teacher education does not give enough preparation for the professional life and consequently newly qualified teachers experience the first years in the field as difficult... The teacher education should thus be changed and more practice should be included...".

Four students suggested a practice-related work. The written work would focus on different aspects of the school work and be related more specifically to the school. The written work could be done in connection to a practice period in order to make the relation to the teacher profession as visible as possible. The pedagogical aspect would thus exist, at the same time as the relation to the practice would become concrete. The students suggested planning and making materials for the teacher profession, for example making plans for the whole school year and teaching materials. Every teacher needs insight into how to make school plans, and according to the students this is missing in the education. School material is also missing in many school subjects and by doing own teaching materials in the education, the students could benefit from it in the future teacher profession, "I would like to make a final work I could then benefit from in the practical work, for example teacher materials or such".

Thirteen students suggested that the research studies and the scientific thesis would be replaced by different courses. The students $(n=6)$ suggested general practical courses as well as practical courses in subjects such as mathematics, biology, and Finnish. These students wanted more practically related courses aiming at giving them ideas and concrete tips for the teaching. The students pointed out that at the beginning of the education they had many funny and concrete courses. However, after the first two years, this kind of courses became more sporadic while the research-based focus became more obvious. The aim of the practical courses was, according to the students, to get more concrete tools for the future working life. The research studies and the theses were thus not experienced by the students as useful with respect to the concrete teacher profession, "Personally I see a bigger use of the practical courses we had during the first years. Then we learnt more concrete how to teach the pupils mathematics, biology, Finnish and so on".

Five students wanted to have more courses in special education. As a consequence of a new law in Finland 2011 (KELPO means in English: The development of support for learning and schooling), the requirements of the primary school teacher to handle pupils with special needs in the classroom have increased. In order to manage the new challenges the reform means, the students wanted to get more insights into special education. The students pointed out that it is required much insight into special education of a teacher at the same time as there is very few courses in special education in the ordinary education, "One disadvantage I see with having research studies and writing a thesis, is that it takes place by other, more important subjects. For example there is very little special education in the compulsory studies, although it is required quite much competence in special education of the teacher".

Three students pointed out that more time should be put on relevant courses such as for example pedagogy and general subjects. The courses should to a higher extent focus on what is really important for the teacher profession and aim would more specifically be to develop the newly qualified teacher and educate better 
teachers, "The question is if the time we spend on learning research methodology would not rather be needed to put on other courses developing us as better teachers instead".

Finally, two students pointed out courses in pre-school education as an alternative to research studies and scientific theses. Within pre-school education students learn to work with younger pupils, which every student teacher would benefit from. If a student lacks necessary knowledge for the upcoming teacher profession, it feels sometimes very hard to put so much emphasis on research studies and writing theses, "Pre-school education is also a subject most students would benefit from, while one learn to work with younger children".

\section{Final Conclusions}

As a result of the study, many positive views $(n=185)$ of the research studies and the scientific thesis could be identified among the students. According to all students, the research studies and the thesis mean something positive and they mentioned aspects as deep knowledge in a subject, a master education and higher status, professionalism, understanding and ability to carry out studies, maturity and personal development, critical thinking, good language, interest for further research, and contribution to something new. Consequently, the students expressed a wide range of positive views, both in relation to their future teacher profession and to themselves. Students' positive views were dominated by views related to their future teacher profession and the positive views expressed in relation to their own personal development were also seen as tools for becoming good teachers. The students thus realized the importance of a research based teacher education.

As a result of the study, some negative views $(n=48)$ of the research studies and the scientific thesis could also be identified among the students. According to 33 students, the research studies and the thesis also mean something negative in terms of a weak relation to the teacher profession, a too large part of the education, pressure and performance anxiety, a too theoretical education for a practical profession, no support for a critical thinking, and no use for the society. In the students' essays, it was very clear that they experienced a too week relation to the teacher profession and that the research studies were a too large part of the education. However, as mentioned before, the students' negative views were accompanied by positive ones, forming together a general understanding of the content and structure of the teacher education.

As a consequence of the students' negative views, some of them also expressed alternatives to the research studies and the scientific thesis. The alternatives $(n=45)$ could be categorized into two main categories, practice and practice-related work, as well as different courses in terms of practical courses and courses in special education, pedagogy, general subjects, and pre-school education. According to the students, the teacher education was thus too theoretical and they wanted more practice, both teacher practice in the field and practical courses. These alternatives were seen by the students as complements to the research studies and the thesis, forming together a better teacher education.

In relation to previous studies (Eklund, 2010, 2012; Eklund-Myrskog, 2006, 2007), students' view of the teacher education has thus changed during the education into a more positive direction and their understanding of the research-based teacher education has increased. A total number of 185 positive views were found in the essays compared to 48 negative views. The alternatives given by the students were also mainly seen as improvements of the teacher education and not as replacements of the research studies and the scientific thesis. This result can be related to previous research within Finnish teacher education (Niemi, 2008). A general result is that the learning culture within teacher education often is passive and receiving, while a more active learning culture is characterizing the master thesis process. This fact thus motivates a research-based teacher education. 
However, although the students understood the importance of having research studies and writing a scientific thesis, they found that the teacher education is too theoretical and that the theoretical part of the education is too dominating. As a consequence, at the very end of the teacher education they still felt very unsafe when discussing their future teacher job in practice. The research-based teacher education thus means a dilemma for the students. They understand it and they see the point with it, but at the same time they feel that it does not give them enough practical tools before entering the reality as a real teacher.

In order to solve the student teachers' dilemma, more emphasis could be put on different projects and development works as well as action research within the education (see for example, Jyrhämä \& Maaranen, 2008). This kind of research approach would to a larger extent correspond to the students' need for a closer connection between theory and practice, which became clear in their essays. In the same way, Niemi (2008) emphasizes a stronger relation between theory and practice and a focus on practice related works in order to develop the Finnish teacher education.

Although the research oriented studies and the master thesis is not anything new within the teacher education in Finland, there is still a need for development. The positive aspect is that the students do not any longer question the research-based teacher education, but realize its importance and relevance for the status of the teacher profession and the teacher's professionalism. The negative aspect is that the students still have difficult to see the relation between the practical teacher profession and the master thesis. The development of the master thesis in direction to different projects and development works as well as action research could be a solution to the students' dilemma.

\section{References}

Bowden, J. A., \& Walsh, E. (Eds.). (2000). Phenomenography. Melbourne: RMIT University Press.

Dahlgren, L. O., \& Fallsberg, M. (1991). Phenomenography as a qualitative approach in social pharmacy research. Journal of Social and Administrative Pharmacy, 8, 150-156.

Eklund, G. (2010). Students' views of the scientific thesis within teacher education in Finland. In G. Eklund, \& J. Sjöberg (Eds.), Att växa till lärare (Specialutgåva Nr. 4). Vasa: Åbo Akademi, Pedagogiska fakulteten.

Eklund, G. (2012). Student teachers' views of research and science within teacher education in Finland. Paper presented at the NFPF Conference, Copenhagen, Denmark.

Eklund-Myrskog, G. (1996). Students' ideas of learning: Conceptions, approaches, and outcomes in different educational contexts. Åbo: Åbo Akademi University Press.

Eklund-Myrskog, G. (2006). Student teachers' ideas of writing a scientific thesis within teacher education in Finland. Paper presented at the European Conference on Educational Research Conference, Geneva.

Eklund-Myrskog, G. (2007). Student teachers' ideas of writing a scientific thesis within teacher education in Finland. Paper presented at the European Conference for Research on Learning and Instruction, Budapest, Hungary.

Hansen, S. E., Forsman, L., Aspfors, J., \& Bendtsen, M. (2012). Visions for teacher education-Experiences from Finland. Acta Didactica Norge, 1(6), 1-17.

Hansén, S. E., Sjöberg, J., \& Eklund-Myrskog, G. (2005). Must know, good to know, nice to know. Kärnstoffsanalys i lärarutbildningar. Nordisk Pedagogik, 4, 400-412.

Harju-Luukkainen, H., \& Nissinen, K. (2010). Finlandssvenska 15 åriga elevers resultatnivå i PISA 2009-undersökningen. Jyväskylä: Jyväskylä universitet, Pedagogiska forskningsinstitutet.

Jakku-Sihvonen, R., \& Niemi, H. (2006). Research-based teacher education in Finland: Reflections by Finnish teacher educators. Research in Educational Sciences, 25. Åbo: Finnish Educational Research Association.

Jyrhämä, R., \& Maaranen, K. (2008). Tutkimuspraktikumi: Maisteripraktikumin ja pro gradu tutkielman integrointi. Didacta Varia, 13(2), 17-30.

Komulainen, J. (2010). Ohjattu harjoittelu luokanopettajaopiskelijoiden ammatillisen kehittymisen tukena (Väitöskirja). Oulu: Oulun yliopisto. 
Marton, F., \& Tsui, A. (Eds.). (2004). Classroom discourse and the space of learning. Mahwah: Lawrence Erlbaum.

Niemi, H. (2008). Advancing research into and during teacher education. In B. Hudson, \& P. Zgaga (Eds.), Teacher education policy in Europe: A voice of higher education institutions (pp. 183-208). Umeå: University of Umeå, Faculty of Teacher Education.

Niemi, H., Hansen, S. E., Jakku-Sihvonen, R., \& Välijärvi. (2007). Lärarutbildning 2020. Undervisningsministerites arbetsgrupp premomemorier och utredningar.

Sahlberg, P. (2011). Finnish lessons: What can the world learn from educational change in Finland? New York: Teachers College Press.

Simola, H., Rinne, R., Varjo, J., \& Kauko, J. (2013). The paradox of the education race: How to win the ranking game by sailing to headwind. Journal of Education Policy, 28(5), 612-633.

Sjöberg, J., \& Hansen, S. E. (2011). Lärarutbildning i ett föränderligt samhälle. In S. E. Hansen, \& L. Forsman (Eds.), Allmändidaktik-Vetenskap för lärare (pp. 73-90). Lund: Studentlitteratur.

Westbury, I., Hansén, S. E., Kansanen, P., \& Björkvist, O. (2005). Teacher education for research-based practice in expanded roles: Finland's experience. Scandinavian Journal of Educational Research, 49(5), 475-485. 